\title{
MELEMAHNYA BUDAYA JAMU CEKOK DI KELURAHAN PARE
}

\author{
Siti Zulaikha ( $\left.{ }^{(}\right)$, Nur Hadi ( $\left.{ }^{2}\right)$, Joan Hesti Gita Purwasih $\left(^{*}\right)$ \\ ${ }^{123}$ Faculty of Social Sciences, Universitas Negeri Malang, East Java, Indonesia
}

\section{ARTICLE INFORMATION}

$\begin{array}{ll}\text { Submitted } & : 26^{\text {th }} \text { November, } 2020 \\ \text { Review } & : 27^{\text {th }} \text { April, } 2021 \\ \text { Accepted } & : 10^{\text {th }} \text { May, } 2021 \\ \text { Published } & : 07^{\text {th }} \text { June, } 2021 \\ \text { Available Online } & : \text { June, } 2021\end{array}$

\section{KEYWORDS}

Jamu; Cekok; Culture; Children; Pare

\section{CORRESPONDENCE}

*E-mail: joan.hesti.fis@um.ac.id

\section{A B S T R A C T}

\section{A. PEndahuluan}

Jamu is a traditional medicine that has been widely known by the Indonesian people. One kind of herbal medicine is now rarely used, namely herbal suppression. The term cekok comes from the Javanese language which means to drink by force. The purpose of this study is to describe how the weakening of the herbal medicine culture in Pare Village. Research using ethnographic qualitative methods with interview and observation techniques. The results of this study indicate that the community sees the existence of herbal suppressants. However, there are not as many devotees as before. As an analytical technique, the author uses an anthropological perspective on medical health behavior according to Notoatmodjo to explain the data found. Data analysis used is the data used, data reduction, and data presentation in the form of descriptions. This study shows that the weakening of the herbal medicine culture, including the number of more modern dietary supplements for children; parents who do not have the heart to do the prostitution process; and the knowledge of parents about the recipe for making the herbal-punching herb.
$\mathrm{P}$ engobatan tradisional merupakan sistem pengobatan sudah di kenal luas oleh masyarakat Indonesia. Penyembuhan penyakit melalui pengobatan tradisional umumnya dilakukan dengan berbagai cara berdasarkan metode yang telah di wariskan nenek moyang. Pengetahuan ini sangat berkaitan erat adat istiadat atau kepercayaan masyarakat lokal, bahkan terkadang bersifat magis (Togobu, 2019). Proses penyembuhan melalui pengobatan tradisional memiliki berbagai metode, di antaranya dengan meracik ramuan dari tumbuh-tumbuhan, penyembuhan secara fisik (pijat, akupuntur, refleksiologi, dan susuk), penyembuhan secara meditasi atau bertapa, dan penyembuhan secara spritual (doa dan mantra-mantra) (Togobu, 2019). Pemilihan pengobatan juga sangat dipengaruhi oleh tingkat pengetahuan dan kepercayan yang telah dianut masyarakat dalam pengobatan sebuah penyakit (etiologi penyakit) (Meiyenti, Maihasni, dan Aziwarti, 2019)

Salah satu pengobatan tradisonal yang cukup banyak digunakan oleh masyarakat Indonesia adalah jamu. Jamu merupakan metode pengobatan tradisonal yang berasal dari racikan tumbuhan, akarakaran dan bahan alami lainya. Sekitar $80 \%$ spesies tanaman obat-obatan dunia tumbuh di Indonesia sehingga, bahan-bahan pembuatan racikan jamu yang dibutuhkan berasal dari alam dan dan mudah ditemui dilingkungan sekitar ((Jennifer dan Saptutyningsih, 2015) . Ramuan jamu dipercaya dan diwariskan resepnya sebagai obat tradisonal secara turun-temurun (Satriyati dan Madura, 2017). Beragam manfaat yang diperoleh dari mengonsumsi 
jamu salah satunya yaitu memlihara kesehatan tubuh, meningkatkan kecantikan, menjaga berat badan serta dapat dijadikan obat alternatif untuk penyembuhan penyakit. Adanya keberadaan pengobatan tradisonal jamu, tidak lepas dari sejarah peradaban manusia di Indonesia. Keberadaan jamu diperkirakan telah ada sejak zaman batu, namun tidak banyak sumber sejarah yang di dokumentasikan secara tertulis. Selama ini sumber sejarah mengenai jamu hanya di wariskan secara lisan. Hal ini diketahui dalam buku The Power of Jamu yang membagi sejarah jamu menjadi 5 (lima) periode. Pertama, periode prasejarah yang ditemukanya fosil manusia purba Pithecantropus. Pada jaman ini diketahui bahwa fosil manusia purba sudah mengetahui penggunaan biomedicine sebagai terapi pengobatan. Kondisi ini ditandai dengan adanya beberapa penyakit yang telah menjangkit manusia pada masa itu. Periode kedua, yaitu sebelum kolonial (sebelum tahun 1600). Dibuktikan dengan pahatan relief yang ada pada dinding Candi Borobudur, yang menunjukan penggunaan ramuan dari tumbuhan sebagai obat. Selain itu, sumber lain keberadaan mengenai jamu dibuktikan dengan naskah kuno yang ditemukan di Bali. Naskah ini ditulis pada daun lontar dengan menggunakan bahasa Sangsekerta pada tahun tahun 991-1016 M (Tilaar dan Widjaja, 2014).

Jamu merupakan bagian dari pengobatan tradisional yang masih menjadi pengobatan alternative yang masih di gemari masyarakat Indonesia dalam mengobati berbagai macam penyakit. Pada jaman dahulu ramuan jamu menggunakan bahan-bahan gampang dijumpai dan yang masih segar karena langsung diambil dari kebun atau halaman rumah. Namun, saat ini masyarakat jarang sekali yang menanam tumbuhtumbuhan yang berpotensi menjadi tanaman herbal. Terbatasnya lahan dan proses yang lama serta kurannya pengetahuan masyarakat mengenai tamana herbal menjadi faktor utama minat masyarakat terhadap jamu berkurang.

Saat ini masyarakat tidak lagi harus bersusah payah menanam dan meraciknya sendiri. Banyaknya macam-macam racikan jamu yang beredar dipasaran memudahkan masyarakat mengonsumsi jamu tradisonal. Dibuktikan dengan riset yang dilakukan Badan Litbang Kesehtan pada tahun 2010 yang menujukan bahwa sekitar $49,53 \%$ masyarakat Indonesia menggunakan jamu baik untuk menjaga kesehatan maupun menjadi obat alternatif untuk mengobati berbagai macam penyakit. Sedangkan, hampir $95 \%$ penduduk Indonesia merasakan manfaat setelah mengkonsumsi jamu. Berdasarkan hasil Riskesdas yang di lakukan Badan Penelitian dan Pengembangan Kesehatan menyebutkan bahwa $55,3 \%$ konsumen cenderung menyukai jamu yang dikemas dalam bentuk cairan (infusum atau decoct), dan sisanya sekitar $44,7 \%$ mengonsumsi jamu dalam bentuk rajangan, serbuk dan pil, kapsul, tablet.

Dalam tradisi masyarakat Jawa pengonsumsian jamu pada umunya hanya diajurkan untuk kaum lansia dan wanita. Namun, Menurut Geertz (1961) obat tradisional bukan semata-mata hanya untuk wanita namun tersedia pula untuk laki-laki dan anakanak. Jamu di khusus untuk anak-anak yang disebut dengan istilah jamu cekok. Istilah cekok merupakan kata yang berasal dari bahasa Jawa yang berarti meminumkan sesuatu dengan cara di paksa. Pemberian istilah cekok pada dasarnya merujuk pada metode pemberian jamu yang dilakukan dengan memasukkan ramuan jamu secara paksa ke dalam mulut anak yang akan diobati (Marni dan Ambarwati 2015). Jamu cekok merupakan pengetahuan local masyarakat yang memiliki beragam khasiat untuk pengobati berbagai macam penyakit ada pada anak. Meskipun demikian, penggunaan ramuan jamu cekok masih menjadi pro dan kontra di kalangana medis maupun masyarakat luas.

Pada masyarakat Kelurahan Pare, Kabupaten Kediri, Provinsi Jawa Timur penggunaan jamu cekok sudah sangat umun digunakan sebagai obat penambah nafsu makan pada anak sejak zaman dahulu. Terbukti dengan dikenalnya daerah Kediri sebagai daerah yang banyak memproduksi olahan jamu. Salah satunya di Kelurahan Pare, yang ditandai dengan banyaknya warung-warung dan toko jamu yang banyak menjual berbagai macam jamu. Akan tetapi, saat ini hanya beberapa warung atau toko jamu yang masih bertahan. Salah satunya toko jamu Singowalisong yang sudah berdiri pada tahun 1982. Toko ini juga sudah sejak lama dan turuntemurun menyediakan berbagai macam racikan ramuan jamu termasuk juga olahan jamu cekok. 


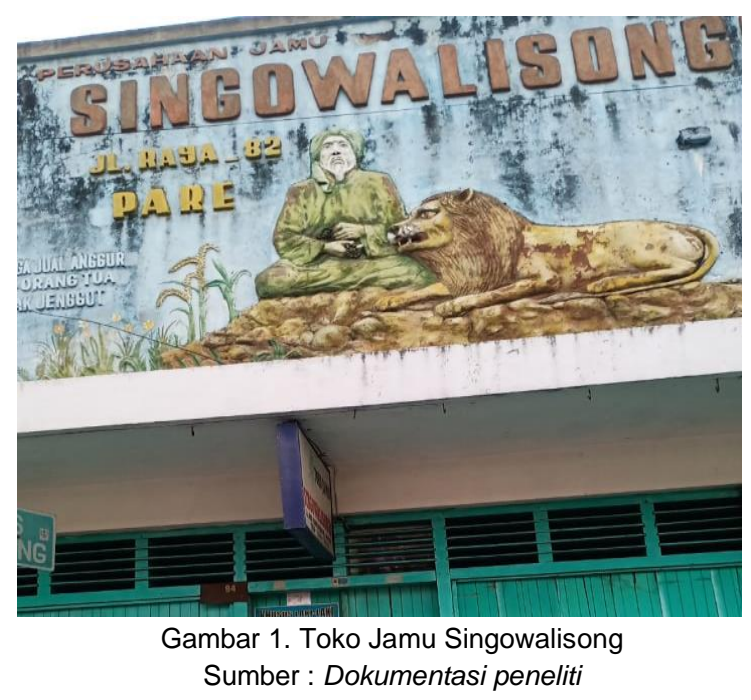

Selain toko jamu songwalisong tersebut masih banyak lagi toko-toko jamu di sekitar wilayah Kelurahan Pare. Toko jamu di Kelurahan Pare sebenarnya sudah mengalami penurunan, misalnya pada tahun 2010 masih ada sekitar 50 an toko produsen jamu. Akan tetapi, berdasatkan hasil obsevasi, kini toko yang tersisa hanya 10 produsen. Berkurangnya produsen jamu di Kelurahan Pare, disebakan oleh menurunnya daya minat masyarakat di Kelurahan Pare terhadap olahan jamu, khususnya jamu cekok. Hal ini dapat dilihat dari survei yang dilakukan peneliti terhadap masyarakat di sekitar Kelurahan Pare. Survei ini dilakukan untuk memperkuat realitas gejala tersebut. Kondisi tersebut dibuktikan dengan data penelitian terkait melemahnya budaya meminum jamu cekok pada anak-anak. Adapun karakteristik subjek pada survei ini sebagai berikut.

Tabel 1. Karakteristik Subjek Penelitian

\begin{tabular}{|c|c|c|c|c|}
\hline No & Nama & Umur & $\begin{array}{l}\text { Pendidikan } \\
\text { terakhir }\end{array}$ & Pekerjaan \\
\hline 1. & Siti Rani & 54 & Tidak sekolah & $\begin{array}{l}\text { Pedagang } \\
\text { jamu }\end{array}$ \\
\hline 2. & $\begin{array}{l}\text { Silvia } \\
\text { Novianti }\end{array}$ & 28 & SMA & $\begin{array}{l}\text { Ibu Rumah } \\
\text { tangga }\end{array}$ \\
\hline 3. & $\begin{array}{l}\text { Dewi } \\
\text { Agustina }\end{array}$ & 34 & S1 & PNS \\
\hline 4. & Yuni & 20 & SMP & Pedagang \\
\hline 5. & Zuana & 23 & SMA & $\begin{array}{l}\text { Ibu Rumah } \\
\text { Tangga }\end{array}$ \\
\hline 6. & Ruti Widiati & 44 & SMA & $\begin{array}{l}\text { Ibu Rumah } \\
\text { tangga }\end{array}$ \\
\hline 7. & $\begin{array}{l}\text { Ayu Anis } \\
\text { syaidah }\end{array}$ & 30 & SMP & $\begin{array}{l}\text { Ibu Rumah } \\
\text { tangga }\end{array}$ \\
\hline 8. & $\begin{array}{l}\text { Eria } \\
\text { Novianti }\end{array}$ & 35 & SMA & $\begin{array}{l}\text { Ibu Rumah } \\
\text { tangga }\end{array}$ \\
\hline 9. & Istiana & 22 & SMA & Pramuniaga \\
\hline 10. & $\begin{array}{l}\text { Siti } \\
\text { Khobsah }\end{array}$ & 32 & SD & $\begin{array}{l}\text { Ibu Rumah } \\
\text { tangga }\end{array}$ \\
\hline 11. & $\begin{array}{l}\text { Vivin } \\
\text { Rahmawati }\end{array}$ & 26 & SMA & Buruh \\
\hline
\end{tabular}

\begin{tabular}{|c|l|c|c|l|}
\hline 12. & Misana & 30 & Tidak sekolah & $\begin{array}{l}\text { Ibu Rumah } \\
\text { tangga }\end{array}$ \\
\hline 13. & Istiana ayu & 29 & SMP & $\begin{array}{l}\text { Ibu Rumah } \\
\text { tangga }\end{array}$ \\
\hline 14. & Estu & 45 & SMA & $\begin{array}{l}\text { Pedagang } \\
\text { makanan }\end{array}$ \\
\hline 15. & Sayem & 50 & SD & $\begin{array}{l}\text { Ibu Rumah } \\
\text { tangga }\end{array}$ \\
\hline 16. & Reni & 48 & SMA & $\begin{array}{l}\text { Ibu Rumah } \\
\text { tangga }\end{array}$ \\
\hline 17 & Yuti & 60 & SD & $\begin{array}{l}\text { Ibu Rumah } \\
\text { tangga }\end{array}$ \\
\hline 18 & $\begin{array}{l}\text { Widia } \\
\text { astuti }\end{array}$ & 49 & S1 & $\begin{array}{l}\text { Ibu Rumah } \\
\text { tangga }\end{array}$ \\
\hline 19 & Widarti & 49 & D3 & Apoteker \\
\hline 20 & Sunarmi & 53 & SMA & $\begin{array}{l}\text { Ibu Rumah } \\
\text { tangga }\end{array}$ \\
\hline
\end{tabular}

Sumber : Survei Penelitian pada Juli 2020

Tabel 2.Tingkat pengetahuan dan penggunaan Masyarakat Kelurahan Pare pada Jamu Cekok

\begin{tabular}{|l|l|c|c|}
\hline \multicolumn{1}{|c|}{ Indikator } & Jawaban & Jumlah & Prosentase \\
\hline $\begin{array}{l}\text { Tingkat Pengetahuan } \\
\text { mengenai Jamu cekok }\end{array}$ & $\begin{array}{l}\text { Tidak } \\
\text { Tahu }\end{array}$ & 11 & $55 \%$ \\
\cline { 2 - 4 } & Tahu & 9 & $45 \%$ \\
\hline $\begin{array}{l}\text { Tingkat penggunaan Jamu } \\
\text { cekok }\end{array}$ & $\begin{array}{l}\text { Tidak } \\
\text { Pernah }\end{array}$ & 16 & $80 \%$ \\
\cline { 2 - 4 } & Pernah & 4 & $20 \%$ \\
\hline
\end{tabular}

Sumber : Survei penelitian pada juli 2020

Tabel 2 menujukkan masyarakat yang mengetahui tentang budaya jamu cekok, tetapi belum tentu menggunakannya pengobatan jamu cekok untuk anak. Dengan demikian, melemahnya jamu cekok di Kelurahan Pare dengan jelas ditemukan melalui hasil survei yang telah dilakukan oleh peneliti.

Ramuan jamu cekok pada umumnya diberikan kepada anak dengan tujuan untuk meningkatkan nafsu makan, obat cacingan, batuk pilek, perut kembung hingga menambah kebugaran tubuh pada anak. Anak-anak yang berusia kisaran 1-2 tahun rata-rata akan mengalami penurunan pada nafsu makan. Penuruna nafsu makan dapat disebabkan oleh berbagai macam faktor salah satunya cacingan sehingga membuat daya tahan tubuh dan berat badan pada anak-anak menurun serta mudah terserang penyakit (Handajani dan Widhiastuti, 2018). Oleh karena itu, para orang tua khususnya ibu-ibu berupaya meracikan atau membeli jamu cekok guna mengatasi pemasalahan kesehatan pada anak tersebut. Akan tetapi, saat ini pengunaan jamu cekok untuk anak-anak sudah kurang diminati. Hal ini mulai tergantikan dengan adanya layanan kesehatan berupa imunisasi yang dilakukan sebulan sekali oleh Posyandu dan di bantu Puskesmas Kecamatan Pare. 
Berdasarkan Peraturan menteri kesehatan Republik Indonesia (PMK) No. 42 tentang Penyelenggaraan Imunisasi. Jenis imunisasi hepatitis B, Polio, BGC, campak, DPT-HB-HiB, hingga imunisasi tambahan perlu di berikan pada anak. Imunisasi tambahan dapat berupa pemberian vitamin atau suplemen untuk anak yang mengalami gangguan penurunan nafsu makan. Pemberian imunisasi pada anak ini dilakukan setiap bulan sekali, kegiatan yang dilakukan mulai dari kontrol berat badan, pemeriksaan, serta pemberian vaksi. Oleh sebab itu, masyarakat pada Kelurahan Pare lebih banyak beralih pada layanan imunisasi Posyandu dari pada menggunakan ramuan jamu cekok untuk meningkatkan nafsu makan dan mengobati berbagai macam penyakit pada anak.

Studi sebelumnya kajian mengenai jamu cekok telah banyak membaha, namun hanya terfokus pada eksistensi jamu cekok sebagai pengobatan alternatif dan pemberian jamu cekok sebagai obat penambah berat badan pada anak (Marni dan Ambarwati, 2015). Penelitian mengenai tingkat penerimaan penggunaan jamu tradisonal sebagai obat alternatif pada konsumen obat modern di masyarakat dengan kelas ekonomi rendah-menengah dan atas (Andriati dan Wahjudi 2016) juga telah dilakukan. Selain itu, terdapat penelitian yang mengungkap jamu cekok sebagai obat menambah nafsu makan dan berat badan pada anak (Handajani, 2019; Handajani dan Widhiastut, 2018; Limananti dan Triratnawati, 2003). Selanjutnya strudi mengenai perilaku masyarakat dalam pemilihan mendapatkan pelayanan pengobatan, antara sikap dengan perilaku mengobati sebuah penyakit. Mengenai tingkap pendidikan masyarakat dalam mengambil tindakan pengobatan.

Berangkat dari realitas dan pertimbangan dari penelitian-penelitian sebelumnya, pada penelitian ini peneliti lebih memfokuskan pada permasalahan latar belakang yang mempengaruhi melemahnya budaya jamu cekok yang merupakan pengetahuan lokal di masyarakat, khususnya terhadap budaya penggunaan jamu cekok di Kabupaten Kediri. Hal tersebut ditandai dengan rendahnya tingkat pengetahuan dan penggunaan ramuan jamu cekok di masyarakat saat ini.

\section{B. METODE PENELITIAN}

$\mathrm{P}$ enelitian ini dilakukan pada Kelurahan Pare, Kecamatan Pare, Kabupaten Kediri. Kelurahan Pare merupakan pusat kota dari Kecamatan Pare yang berada di timur Kota Kediri.
Kelurahan Pare merupakan wilayah terkecil di Kecamatan Pare dengan luas hanya sekitar 2,28 $\mathrm{Km}^{2}$. Lokasi penelitain cukup mudah di jangkau karena dekat dengan pusat kota dan berdekatan dengan lokasi Kampung Inggris Pare.

Adapun jenis penelitian yang di gunakan dalam penelitian ini yaitu kualitatif. Penggunaan metode ini dimaksudkan guna mengetahui gambaran atau kondisi mengenai penggunaan pengobatan tradisional jamu cekok pada masyarakat di Kelurahan Pare. Pendekatan kualitatif dipilih untuk menafsirkan dan memahami pola-pola perilaku, nilai, dan kepercayaan masyarakat dari berbagai kelompok budaya (Cresswell 2007). Peneilitian ini menjelaskan latar belakang tentang pengobatan jamu tradisonal, jamu cekok sebagai pengetahuan lokal yang mulai melemah. Sementara, menurut Bogdan dan Taylor, (1975) penelitian kualitatif merupakan suatu metode penelitian dengan proses penelitian yang menghasilkan data deskriptif berupa data tertulis atau lisan dari subjek dan objek yang diamati.

Subjek dalam penelitian ini sekitar 20 orang informan dan rata-rat merapakn ibu-ibu di Kelurahan Pare. Subjek penelitian terdiri dari penjual jamu cekok, konsumen jamu khusunya ibu-ibu dan informan yang masih menggunakan pengobatan tradisonal jamu cekok dan masyarakat yang sudah tidak menggunakan pengobatan tradisonal jamu cekok. Teknik pengumpulan data dilakukan melalui wawancara dan observasi lapangan. Analisis data dilakukan mealui tahapan pengumpulan data, reduksi data, dan penyajian. Selanjutnya, hasil penelitian ini disajikan dalam kategorisasi kesamaan hasil pemetaan persepsi dan pengalaman bersama antar informan.

\section{HASIL DAN PEMBAHASAN}

\section{Mengenal Jamu Cekok Masyarakat Kelura han Pare}

$\mathrm{K}$ ediri merupakan salah satu daerah yang dikenal banyak memproduksi jamu di Indonesia. Tak terkcuali di Kelurahan Pare yang merupakan bagian dari kediri yang terdapat banyak warung-warung penjual jamu. Kelurahan Pare dahulu merupakan daerah yang banyak terdapat penjual jamu pada tahun 90 an. Kondisi ini ditandai dengan banyaknya bekas warung dan toko penjual jamu di sepanjang jalan raya Keluarahan Pare. Oleh karena itu, masyarakat di Kelurahan Pare sangat tidak asing lagi dengan pengobatan 
tradisonal ramuan jamu. Masyarakat memilih jamu tradisional sebagai obat alternatif untuk menyembuhkan berbagai macam penyakit, termasuk juga untuk meningkatkan nafsu makan pada anak seperti jamu cekok.

Berdasarkan hasil pengamatan di lapangan, ditemukannya banyak bekas warung-warung jamu yang sudah tutup dan tidak beroprasi lagi disepanjang jalan raya di Kelurahan Pare. Kondisi bekas warung-warung jamu ini tersebar di beberapa titik jalan raya di Kelurahan Pare seperti yang tampak pada gambar 2 .

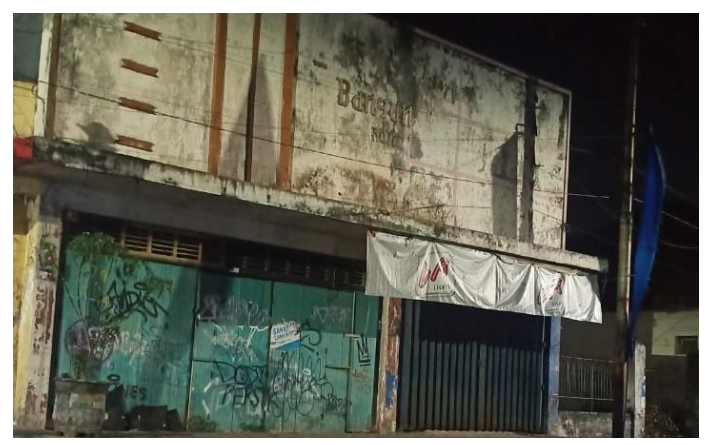

Gambar 2. Toko jamu yang sudah tidak beroperasi Sumber : dokumentasi peneliti

Masih adanya beberapa warung-warung jamu kecil yang masih bertahan hingga saat ini. Namun, toko-toko tersebut sudah jarang sekali menyedikan olahan ramuan jamu cekok. Rata-rata pedagan jamu lebih banyak memproduksi jamu yang dikhususkan hanya untuk penyembuhkan penyakit pada orangorang dewasa. Meskipun demikian, jika konsumen ingin membeli jamu cekok, warung jamu tersebut akan meracikan jamu cekok jika konsumen memesan terlebih dahulu.

Adapun bahan dasar dari jamu cekok Jamu cekok ini yang terbuat dari berbagai macam rempahrempah yang ganpang sekali ditemui di Indonesia. Sehingga selain dapat dipesan di warung-warung jamu, racikan ramuan jamu cekok juga dapat dibuat sendiri di rumah. Berikut ini merupakan resep dan proses pembuatan jamu cekok sebagai berikut.

\section{a) Bahan Baku Pembuatan Jamu Cekok}

Pada dasarnya tidak ada resep pasti dalam pembuatan jamu cekok karena hal ini tergantung pada kepercayaan yang telah diajakan oleh generasi sebelumnya. Masyarakat sering kali menggunakan empon-empon yang tersedia di sekitar rumah atau yang sering dijual di pasaran. Empon-empon sendiri merupakan penyebutan dari rempah-rempah yang biasanya dihgunakan pada jamu tradisional Jawa. Sehingga resep pembuatan ramuan jamu cekok sangatlah beragam. Namun resep ramuan yang dimiliki tiap peramu dapat berbeda-beda, mulai dari penggunaan bahan baku sederhana hingga penggunaan bahan baku yang paling kompleks. Bahan baku sederhana biasanya hanya terdiri dari temulawak yang di campur dengan asam jawa. Jamu cekok yang terbuat dari bahan empon-empon alami tanpa campuran bahan kimia seperti pemanis buatan maupun bahan pengawet.

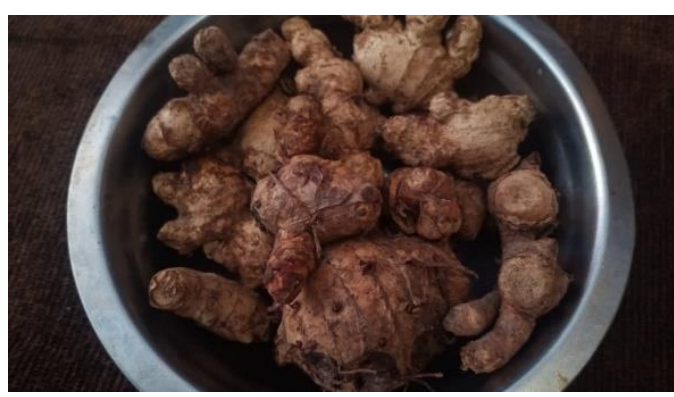

Gambar 3. Empon (kencur, jahe,temulawak, kunyit, temuireng, dan lempuyang emprit) Sumber : dokumentasi peneliti

Komposisi ramuan jamu cekok yang paling kompleks yaitu empon-empon yang terdiri dari: temulawak (Curcuma xanthorrhiza Roxb), kencur (Kaempferla galanga L), jahe (Zingiofficinale Rosc), kunyit (Curcuma domesticaVal.), temu ireng (Curcuma aeruginosa Roxb), dan lempuyang emprit (Zingiber americans L), brotowali (Tinospora tuberculata Beumee) dan daun pepaya (Carica papaya $L$ ). Tetapi ada beberapa orang tua yang menambahakan ramuan jamu cekok dengan bahan-bahan yang dirasa cukup tidak lazim salah satunya seperti tempe busuk yang dipercayai memiliki berkhasiat dapat menambah nafsu makan pada anak.

b) Proses Pembuatan dan penggunaan Jamu Cekok

Proses pembuatan jamu cekok yaitu, pertama menyiapkan bahan ramuan jamu yang berasal dari empon-empon (kencur, jahe,temulawak, kunyit, temuireng, dan lempuyang emprit) yang sudah dikupas dan dicuci bersih; langkah kedua, bahan yang tersebut lalu dihaluskan atau ditumbuk sampai halus serta tambahkan sedikit air matang; langkah ketiga, setelah bahan halus ramuan di masukan ke dalam kain untuk diperas agar dapat diambil sari-sarinya. 


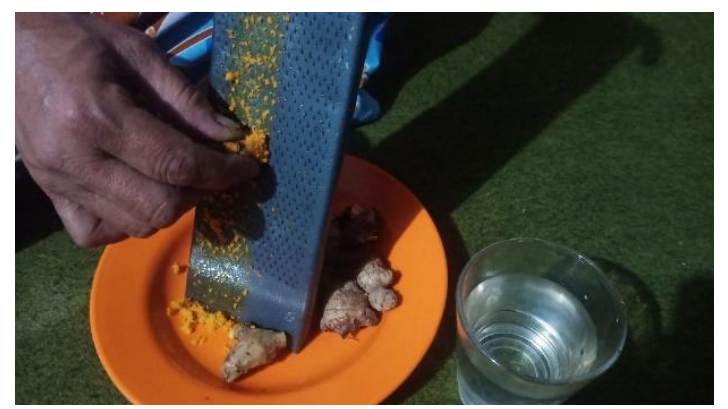

Gambar 4. Pemarutan bahan jamu cekok Sumber : dokumentasi peneliti

Penggunaan kain pada proses pencekokan pada umumnya di fungsikan sebagai saringan (Handajani dan Widhiastuti 2019). Adapun dalam proses pemerasan ramuan jamu menggunakan kain putih yang berbahan siffon. Proses pemerasan dilakukan dengan cara memenpatkan bahan-bahan ramuan jamu yang sudah di haluskan sebelumnya diatas di kain putih tipis. Penggunaan kain putih tipis bertujuan agar terhindar dari pencemaran warna pada ramuan jamu cekok, dan dianggap lebih bersih serta memudahkan pada proses pencekokan.

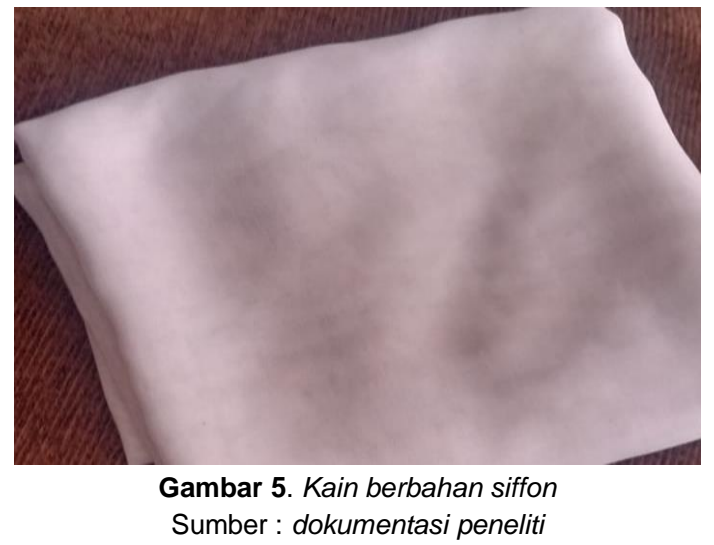

Langkah awal pemberian jamu cekok kepada anak yaitu pertama anak di posisikan dengan nyaman seperti dipangku atau digendong. Selanjutnya, ramuan yang sudah di bungkus dengan kain diberikan kepada anak dengan diawali memencet hidung anak hingga mulutnya terbuka. Saat mulut anak terbuka, jamu yang dibungkus kain diperas di atas mulut anak hingga cairan secara perlahan-lahan masuk ke dalam mulut.

Biasanya anak-anak akan langsung bereaksi menolak karena aroma serta rasa pada jamu cekok terasa pahit dan getir. Akan tetapi, jika jamu diberikan pada anak-anak yang sudah besar atau berumur lebih dari lima tahun, mereka umumnya akan mengerti tujuan minum jamu. Teknik yang digunakan pun menjadi berbeda sehingga biasanya mereka akan diberi dalam gelas kecil. Meskipun jamu diberikan kepada anak-anak dengan diminumkan melalui gelas atau sendok. istilah cekok masih saja di gunakan.

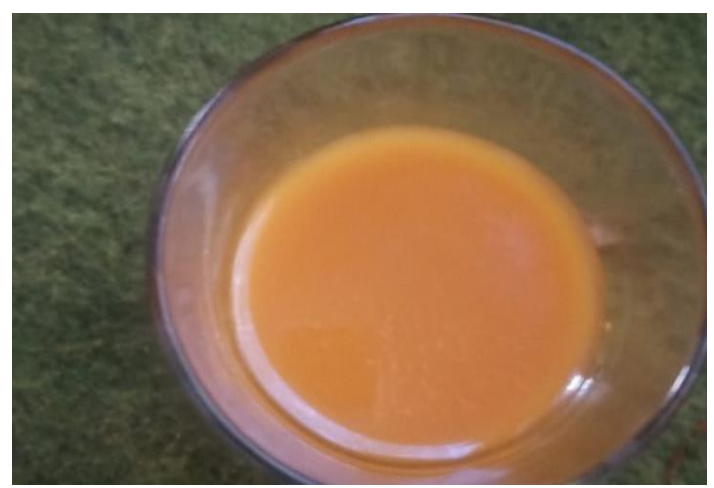

Gambar 6. Jamu Cekok dalam bentuk Sumber. dokumentasi peneliti

\section{Penyebab Melemahnya Budaya Jamu Cekok}

Gejala melemahnya minat masyarakat terhadap pengobatan tradisional jamu cekok sudah dipaparkan dan dibuktikan pada latar belakang penelitian ini. Meskipun jamu terkenal memiliki berbagai macam khasiat yang dapat menyembuhkan berbagai macam penyakit salah satunya jamu cekok yang dapat gunakan untuk menambah napsu makan pada anak. Dari hasil penelitian ini menunjukkan bahwa adanya bebra faktor yang penyebab budaya jamu cekok mulai ditinggalkan oleh masyarakat Kelurahan Pare yaitu adanya menganggap penggunaan pengobatan tradisional seperti jamu cekok tidak praktis dan kurang teruji tingkat keefektifitasnya. Hal ini dikarenakan penggunaan jamu cekok Hanya berdasarkan pandangan atau kepercayaan yang turun-menurunkan oleh keluaraga atau saran-saran dari orang terdekat seperti teangga dan teman sehingga beberapa penggunanya yang masih bertahan menggunakanya.

Banyaknya proses dalam langkah pembuatan jamu cekok mulai dari pemilihan bahan baku hingga resep atau aturan dalam pembuatannya yang masih belum teruji secara medis baik mutu dan keamanan dalam penggunaanya, yang membuat jamu cekok menjadi kurang diminati sehingga budaya melemah di kalangan masyarakat. Selain itu beberpa faktor pendukung melemahnya budaya jamu cekok yaitu sebagi berikut 


\section{a. Suplemen Instan Penambah Nafsu Makan Lebih Digemari.}

Semakin cepetnya laju perkembangan teknologi saat ini, serta semakin bertambahnya jumlah penduduk yang lebih modern, membuat masyarakat pengguna pengobatan tradisional semakin berkurang termasuk penggunaan jamu cekok di masyarakat sebagai obat penambah napsu makan pada anak, mulai mengalami penurunan. Kondisi ini terjadi disebabkan oleh kecenderungan masyarakat saat yang lebih minat kepada obat-obatan kimia karena lebih praktis dari pada jamu tradisional (Widiyanti, 2005). Salah satunya seperti penggunaan suplemen instan sebagai penganti jamu cekok.

$\mathrm{Di}$ Indonesia, penggunaan suplemen instan termasuk kedalam kategori makanan dan terdaftar sebagai obat tradisional (Ramadani, 2007). Produk-produk suplemen makanan yang banyak beredar dipasaran, memilki ditatur dalam Surat Keputusan Direktorat Jenderal Pengawasan Obat dan Makanan (BPOM) No. HK 00.063.0236. Sehingga hasil data dilapangan menunjukkan masyarakat memiliki presepsi suplemen makan instan memiliki fungsi yang sama dan terkesan jauh lebih efektif dan terjamin kemana serta mutu dalam suplemen instan. Oleh karena itu, penggunaan jamu cekok mulai ditinggalkan dan diganti dengan sumplemen makan instan. Hal ini juga terjadi pada penggunaan suplemen makan instan sebagai penganti budaya jamu cekok sebagai obat penambah nafsu makan. Berdasarkan data hasil observasi di lapangan memperlihatkan bahwa suplemen makan instan lebih digemari karena harganya terjangkau, tersedia berbagai macam rasa dan mencerminkan perilaku kesehatan yang lebih modern. Kondisi tersebut secara umum mencerminkan masyarakat modern saat ini yang cenderung menyukai jenis makan yang instan, praktis dan siap saji serta mengandung beragam zat yang kurang baik bagi tubuh (Australian Institute Of Health And Welfare, 2012).

Orang zaman dulu lebih akrab dengan jamu cekok dari pada dengan suplemen instan karena dirasa alami dan masih terbatasnya pengetahuan dan fasilitas kesehatan. Selain itu masih banyaknya tumbuhan-tumbuhan untuk meracik jamu yang ditanam disekitar rumah menjadi faktor jamu cekok sangat eksis digunakan pada zaman dahulu. Sehingga mereka cenderung masih terpaku dengan obat-obatan tradisonal seperti jamu cekok dalam menangani masalah penurunan nafsu makan pada anak. Namun seiring dengan majunya perkembangan teknologi dalam medis, banyak munculnya industri pembuatan suplemen penambah nafsu makan instan. Penggunaan suplemen instan banyak di gunakan oleh masyarakat pada Kelurahan Pare saat ini karena penyajiannya paraktis, pilihan di pasaran beragam, dan harga yang ditawarkan cukup terjangkau baik di kalangan kelas atas atau pun kelas bawah.

Semua ada zat-zat yang diperlukan untuk penambah nafsu makan pada anak sudah ada dalam satu paket dalam suplemen makan instan. sehingga suplemen tersebut banyak digemari oleh masyarakat. Suplemen instan saat ini banyak tersedia dengan berbagai macam rasa dan bentuk yang menarik, mulai dari suplemen makan berbebtuk permen, kapsul, maupun sirup.

\section{b. Orang Tua yang Tidak Tega Melakukan Proses Pencekokan pada Anak \\ Kegiatan mencekok biasanya dilakukan pada} balita yang menolak memimum obat atau jamu yang bertujuan menyembuhkan suatu penyakit atau untuk penambah nafsu makan. Proses pencekokan yang dilakukan pada balita yang sedang mengalami penurunan nafsu makan dilakukan dengan cara megucurkan langsng ramuan jamu yang teah di bungkus dengan kain diatas mulut anak. Namun biasanya dalam proses pelaksanaanya anak-anak akan cenderung akan bereaksi menolak karena rasa yang pait dan getir dan aroma jamu yang terkesan bau tidak sedap sehingga anak-anak kurang tertarik (Koesoemawardani, dkk, 2018). Proses pencekokan biasanya memerlukan waktu singkat, tergantung tingkat kesulitan yang dihadapi dalam menangani anak yang saat dicekok.

Berdasarkan hasil wawancara kepada berbagai konsumen dan penjual jamu, kegiatan mecekok jamu saat ini yang mulai kurang diminati orang tua modern disebabkan perasaan tidak tega saat melihat anak menangis dan memberontak pada saat melakukan proses pencekokan. Sangat wajar jika saat menjalani proses pencekok anak akan bereaksi menagis, meronta-ronta, hingga memuntahkan ramuan jamu yang akan di cekokan. Hal ini dipandang cukup beresiko karena akan membuat anak menjadi trauma terhadap makanan dan minuman. Selain itu, orang tua juga mengaku takut ketika anak tersedak saat proses pencekokan. Jika anak tersedak maka akan mengakibatkan resiko kesulitan bernafas hingga menyebabkan meninggal, apalagi jika anak masih berusia dini atau bayi. 
c. Kurangnya Pengetahuan Masyarakat

Mengenai Resep Pembuatan Jamu Cekok

Pada pembahasan sebelumnya sudah di jelaskan mengenai bahan baku yang digunakan dalam pembuatan ramuan jamu cekok. Namun pada setiap keluarga atau peramu yang membuat jamu cekok memiliki berbagai macam versi masing-masing resep ramuan jamu yang sesuai dengan kepercayaan dan ajaran dari generasi sebelumnya. Hal demikian disebabkan karena pengetahuan tentang pembuatan ramuan jamu pada umunya tidak diajarkan secara pasti pada pendidikan formal, melainkan di hanya di peroleh dari pengalaman pribadi dan resep turun-temurun dari orang tua.

Resep pembuatan jamu cekok pada setiap peracik atau peramu memiliki takaran dan bahan baku yang berbeda beda yang sesuai dengn tingkat pengetahuan peramu tersebut. Racikan ramuan jamu biasanya menggunkan bahan baku empon-empon mulai dari yang sederhana hingga paling kompleks. Empon-empon adalah sebutan untuk tanaman-tanaman herbal yang biasanya digunakan untuk bahan baku pembuatan jamu. Penggunaan bahan baku alami seperti emponempon ini dianggap memiliki efek samping yang minim dari pada obat-obatan kimiawi (Pahandayani, 2014).

Meskipun begitu banyak masyarakat di Kelurahan Pare yang meninggalkan budaya minum jamu cekok pada anak karena dikarenakan kurang pengetahuan masyarakat tentang pembuatan, aturan pakai, dan dosis yang pasti dalam penggunaan jamu cekok. Dengan demikian jika dalam proses peracikan ramuan jamu cekok, si peramu tidak menggetahui secara pasti takaran bahan baku dan kanduang khasiat di setiap bahan baku maka akan sangat berbahaya apabila dikonsumsi khususnya diberikan pada anak-anak. Hal tersebut yang menyebakan orang tua jarang meracik sendiri dan memberikan ramuan jamu cekok untuk mengobati penyakit pada anak.

Tak adanya regenerasi pada produsen jamu juga turut mendukung faktor melemahnya budaya jamu cekok di masyarakat. Dimana biasanya produsen jamu atau peracik jamu sudah jarang sekali mewariskan pada generasi selanjutnya. Kegiatan produksi jamu peracikan jamu pada saat ini dipandang kurang menguntungkan dari segi ekonomi. Penggunaaan pengobatan tradisonal jamu yang sudah diangap kuno bagi generasi muda saat ini, sehingga mereka kurang minat dalam mempelajari racikan obat-obatan tradisonal seperti jamu cekok ini.

\section{Perubahan Perilaku Kesehatan Masyarakat dalam Perspektif Antropologi}

Menurut Notoatmodjo (2007), perubahan perilaku masyarakat umunya membutuhkan proses yang komplek dan memakan rentan waktu yang relatif lama. Pada penelian ini, melemahnya penggunaan jamu cekok dapat dijelaskan melalui tahapan yang dikemukakan Notoatmodjo. Adapun tahapan yang dibutuhkan dalam perubahan perilaku pada masyarakat terkait kesehatan yaitu pengetahuan, sikap, dan tindakan.

\section{a. Pengetahuan Kesehatan (Health Knowledge)}

Pengetahuan merupakan sebuah hasil dari sebuah rasa penasaran. Rasa penasaran tersebut dapat terjadi setelah sesorang melakukan pengindraan terhadap suatu objek tertentu. Pengindraan yang dilakukan pada suatu objek dapat berupa melihat, merasakan, dan mendengar. Pengindraan yang telah diakukan biasanya seseorang akan lebih mengetahui. Sehingga hal tersebut biasanya dapat mempengaruhi terbentuknya suatu sikap atau tindakan sesorang.

Pengetahuan seseorang mengeni kesehatan dapat terlihat jika ia mengetahui cara-cara dalam menjaga kesehatan. Indikator pengetahuan kesehatan dapat diketahui melalui pemahaman mengenai sakit dan penyakit, gaya hidup sehat, serta pengetahuan tentang kesehatan lingkungan. Adapun pada penelitian ini pengetahuan masyarakat Kelurahan Pare terhadap kesehatan juga dipengerahui oleh pengalaman dan perkembangan teknologi yang ada. Pengetahuan masyarakat tentang indikator kesehatan banyak berasal dari pengalaman pribadi individu dan orang yang ada di sekitarnya. Misalnya, pengetahuan masyarakat mengenai ramuan jamu cekok yang dapat menambah nafsu makan sudah terjadi melalui sosialisasi antargenerasi dan menjadi pengetahuan lokal masyarakat. Meskipun demikian, adanya kemajuan kehidupan di berbagai bidang kini membuat masyarakat dapat dengan mudah memperoleh informasi tentang kesehatan modern. Kondisi ini ditandai sejak adanya peran Posyandu bagi masyarakat. Pengetahuan baru terkait kesehatan anak mulai menggeser cara-cara orang tua dalam memberikan penanganan kesehatan anak. Selain itu, hadirnya informasi suplemen- 
suplemen makanan yang lebih praktis di pasaran juga memengaruhi orientasi orang tua.

\section{b. Sikap Terhadap Kesehatan (Health Attitude)}

Sikap merupakan reaksi atu respon yang terjadi setelah adanya pengatahuan tentang suatu objek. Sikap dapat mencerminkan kesenangan atau ketidaksenangan seseorang terhadap sesuatu. Sikap dapat timbul dari pengalam individu sendiri atau orang lain. Selain itu sikap juga berperan menjadi predisposisi dalam bereaksi dengan cara menyukai atau menolak terhadap suatu kondisi. Adapun unsur yang berpengaruh terhadap sikap dalam perilaku kesehatan masyarakat dalam penelitian ini antaranya pengalaman pribadi. Pengalaman pribadi karena adanya pengaruh yang melibatkan faktor emosinal. Hal tersebut juga terjadi pada sikap masyarakat dalam menyikapi penggunaan jamu cekok masyarakat. Misalnya, pada temuan penelitian ini sebagian orang tua tetap menggunakan jamu cekok sebagai pengobatan penambah nafsu makan karena adanya pengalaman pribadi semasa mereka kecil. Akan tetapi, ada pula kondisi ketika orang tua tidak lagi mau menggunakan karena tidak tega melihat anak mengalami pencekokan.

\section{c. Tindakan Kesehatan}

Tindakan kesehatan (health practice) atau tindakan gaya hidup sehat merupakan sebuah kegiatan seseorang untuk menjaga kesehatan. Ada perbedaan antara sikap dan tindakan, sikap belum tentu terwujud jika di dalanmnya tidak ada tindakan (over behavior). Sebuah tindakan atau perbuatan yang nyata diperlukan faktor pendukung. Selain itu Upaya individu dalam mendapatkan kesehatan merupakan suatu pranata khusus dilakukan dan dikembangkan pada masa primitive. Pemahaman dan kepercayaan seseorang terhadap kesehatan tidak lepas dari pengaruhi budaya dan peradaban primitif (Foster dan Anderson, 1986). Budaya manusia terdapat tindakan kesehatan juga selalu berkembang, karena pemahaman masyarakat mengenai kesehatan berpengaruh juga terhadap tindakan yang dilakukannya.

Adapun dalam penelitian ini faktor pendukung pada perilaku kesehatan di wujudkan dengan terpenuhinya fasilitas kesahatan seperti Posyandu. Sementara itu, penyedia jamu cekok juga semakin minim, sehingga dirasa kurang praktis oleh masyarakat. Oleh karena itu, tidak heran tindakan masyarakat dalam memanfaatkan jamu cekok sebagai pengobatan tradisional semakin memudar.

\section{KESIMPULAN}

amu cekok merupakan wujud dari sebuah pengetahuan lokal mengenai pengobatan tradisonal di Indonesia. Akan tetapi, kini ini masyarakat lebih cenderung memilih pengobatan alternatif dengan proses penyembuhan yang secara instan. Pemilihan pengobatan masyarakat ini juga tak lepas dari tingkat pengatahuan dan kepercayaan yang telah dianut di masyarakat. Akibarnya orientasi dan perilaku dalm kesehatan masyarakat mulai berubah serta mengalami pergeseran. Pada kondisi ini pengetahuan lokal terkait jamu cekok menjadi simbol memudarnya kehidupan tradisional menuju kehidupan masyarakat modern. Pertentangan antara tradisionalisme dan modernisme pada ini masih sering terjadi.

Banyaknya faktor yang menyebabkan pengobatan tradisional seperti jamu cekok ini mulai kurang diminati oleh masyarakat. Faktor yang mempengaruhi yaitu masyarakat yang mulai terbuka dengan teknologi pada pengobatan modern yang terkesan instan dan praktis. Salah satu penggunaan pengobatan modern dalam hal ini yaitu penggunaan suplemen instan. Proses pencekokan yang cenderung berbahaya dan terkesan memaksa anak membuat orang tua takut melakukan tidakan pencekokan serta tak adanya takaran atau aturan pasti dalam pembuatan ramuan jamu juga membuat orang tua takut menggunakan atau meracik jamu cekok.

Lemahnya regenerasi dalam produsen jamu juga turut andil dalam melemahnya buadaya jamu cekok dimasyarakat. Proses produksi jamu umumnya hanyalah dikelolah oleh usaha keluarga inti yang diturunkan, turun-temurun ke sang anak. Pada era ini usaha keluarga yang memproduksi jamu sudah mulai jarang mengajarkan ramuan pembuatan jamu pada generasi berikutnya. Adanya anggapan bahwa usaha pembuatan jamu yang terkesan kuno, kurang menghasilkan secara ekonomi, dan rumitnya proses pembuatan merupakan penyebab sulitnya regenerasi dilakukan. Sehingga melemahnya regenerasi pada produsen jamu juga turut berpengaruh terhadap melemahnya budaya penggunaan jamu cekok dimasyarakat.

Saran yang direkomendasikan oleh penulis pemerintah lebih peduli dengan produsen jamu. Ditujukan dengan adanya pengujian secara klinis pada produk-produk jamu agar kepercayaan dan minat masyarakat meningkat terhadap produkproduk jamu yang beredar dimasyarakat. Selain itu adanya pelatihan atau sosialisasi tingakat desa atau kelurahan terkait tanaman rempah-rempah yang 
berpotensi dijadikan obat herbal. Adanya komodifikasi budaya juga dapat berpotensi menunjang kembali eksisnya budaya meminum jamu khususnya jamu cekok. Selain Menghidupkan kembali budaya lama namun dilakukan dengan caracara yang baru dan bentuk produk yang baru yang sesuai dengan saat ini (Purwasih,dkk.2019). Salah satunya dengan mengubah ramuan jamu dengan menginovasikan kedalam bentuk-bentuk contohnya jamu yang dikemas dalam bentuk permen, cemilan atau makan dan minuman lainya. Agar dapat menarik minat anak dalam mengonsumsinya.

\section{E. UCAPAN TERIMAKASIH}

$\mathrm{T}$ erima kasih penulis sampaikan kepada Universitas Negeri Malang atas kesempatan untuk menulis artikel ini sebagai hasil penganti penelitia pada skripsi. Demikian halnya dengan pihak masyarakat di Kelurahan Pare yang telah bersedia memberi kesempatan kepada penulis untuk mengumpulkan data yang dibutuhkan selama penelitian.

\section{DAFTAR PUSTAKA}

Australian Institute Of Health And Welfare. 2012. "Australia's Food and Nutrition 2012." https://www.aihw.gov.au/reports/food-nutrition/australias-food-nutrition-2012/contents/table-of-contents (Agustus 30, 2020).

Bogdan, R., Taylor, S. J., \& Taylor, S. S. 1975. "Introduction to qualitative research methods: A phenomenological approach to the social sciences. Wiley-Interscience."

Cresswell, John W. 2007. "Qualitative Inquiry and Research Design: Choosing Among Five Traditions." Western Journal of Nursing Research 21(1): 103-5.

Eisenstadt, Shmuel N. 1977. Revolusi dan Transformasi Masyarakat,. jakarta: CV Rajawali.

Foster, Anderson, G.M, B.G. 2006. Antropologi Kesehatan. Jakarta: Penerbit Universitas Indonesia.

Geertz H. 1961. Keluarga Jawa. Jakarta: PT. Grafiti Press.

Gita Purwasih, Joan Hesti, Mahendra Wijaya, dan Drajat Tri Kartono. 2019. "Strategi Bertahan Hidup Perajin Gerabah Tradisional." Jurnal Antropologi: Isu-Isu Sosial Budaya 21(2): 159.

Handajani, Sih Rini, dan KH Endah Widhiastuti. 2018. "Pengaruh Jamu Cekok Terhadap Kenaikan Berat Badan Dan Jumlah Makanan Yang Dikonsumsi Mencit." Jurnal Kebidanan dan Kesehatan Tradisional 3(2). http://jurnalbidankestrad.com/index.php/jkk/article/view/73 (Juni 2, 2020).

Husaini, Husaini et al. 2017. BUKU AJAR Antropologi Sosial.

Jennifer, Herika, dan Endah Saptutyningsih. 2015 "PREFERENSI INDIVIDU TERHADAP PENGOBATAN TRADISIONAL DI INDONESIA." 16: 16.

Koesoemawardani, Dyah, Sri Hidayat, dan Fibra Nurainy. "PEMBUATAN PERMEN JAMU CEKOK SEBAGAI UPAYA DIVERSIFIKASI PRODUK JAMU DI KECAMATAN BUMIRATU NUBAN KABUPATEN LAMPUNG TENGAH." : 5.

Marni, Marni, dan Retno Ambarwati. 2015. "KHASIAT JAMU CEKOK TERHADAP PENINGKATAN BERAT BADAN PADA ANAK." Jurnal Kesehatan Masyarakat 11(1): 102.

Meiyenti, Sri, Maihasni Maihasni, dan Aziwarti Aziwarti. 2019. "Faktor-faktor Budaya Penghambat Penderita Kanker Berobat ke Fasilitas Pengobatan Modern." Jurnal Antropologi: Isu-Isu Sosial Budaya 21(2): 142.

PAHANDAYANI, P. (2014). Faktor-Faktor yang Berhubungan Dengan Pemilihan Pengobatan Alternatif Jamu Pada Pasien Diabetes Melitus Di Rumah Riset Jamu Hortus Medicus Tawangmangu (Doctoral dissertation, Universitas Muhammadiyah Surakarta).

"PMK No. 42 ttg Penyelenggaraan Imunisasi.pdf." https://peraturan.bkpm.go.id /jdih/userfiles/batang/PMK\%20No.\%2042\%20ttg\%20Penyelenggaraan\%20Imunisasi.pdf (Juni 2, 2020).

Ramadani, Mery. 2007. "KONSUMSI SUPLEMEN MAKANAN DAN FAKTOR- FAKTOR YANG BERHUBUNGAN PADA REMAJA SMA ISLAM AL - AZHAR 3 JAKARTA SELATAN TAHUN 2005." Jurnal Kesehatan Masyarakat 1(2): 5.

"Riskesdas $2010 \quad$ Nasional.pdf." http://kesga.kemkes.go.id/images/pedoman/Riskesdas\%202010\%20 Nasional.pdf (Juni 4, 2020).

Satriyati, Ekna, dan Universitas Trunojoyo Madura. 2017. "Menjaga Tradisi Minum Jamu Madura Dengan Penyampaian Pesan Interpersonal Kesehatan Antara Peramu Dan Pengguna." 10(2): 12.

Widiyanti, H. (2005). Sejarah Perkembangan Industri Jamu Tradisional dan Pengaruhnya Terhadap Kehidupan Sosial Ekonomi Masyarakat Gentasari Kecamatan Kroya Kabupaten Cilacap Tahun 19902002 (Doctoral dissertation, Universitas Negeri Semarang).

56 | P a g e

https://doi.org/10.25077/jantro.v23.n1.p47-57.2021 
Tilaar, Widjaja, Martha, Bernard T. 2014. The Power of Jamu. jakarta: Gramedia Pustaka Utama.

Togobu, Dian Mirza. 2019. "Gambaran Perilaku Masyarakat Adat Karampuang Dalam Mencari Pengobatan Dukun (Ma'sanro)." J-KESMAS: Jurnal Kesehatan Masyarakat 4(1): 16. 